\title{
Do Personality Types Make Consumers Exhibit Different Complaint Behaviors?*
}

\author{
Olgun Kitapci \\ Associate Prof. Dr. Akdeniz University, \\ Marketing Dept. Antalya/Turkey, \\ E-mail: okitapci@akdeniz.edu.tr. \\ Ibrahim Taylan Dortyol \\ Assistant Prof. Dr. Akdeniz University, \\ Marketing Dept. Antalya/Turkey.
}

Received: 16.08.2015 / Revised: 18.09.2015 / Accepted: 13.10. 2015 / Published online: 30.12.2015

\begin{abstract}
This study aims to explore the differences and similarities in complaint behavior of consumers according to their personality types. 116 managers of a large Turkish finance company have participated in the study. Results show that Intuition-Thinking and Sensing-Thinking individuals tend to engage in public action, while Sensing-Feeling individuals prefer to take private action, and Intuition-Feeling individuals take no action, which is a different form of complaint behavior.
\end{abstract}

JEL classification: M39 and M12

Keywords: Complaint behavior, personality type, Jung's theory, Myers-Briggs type indicator, Turkey

\section{INTRODUCTION}

Customer retention is regarded as one of the major forces of competitiveness. The cost of gaining a new consumer is deemed as being far and away higher than the cost of protecting an existing consumer (Blodgett et al., 1995; Duffy, 2003). According to Lee et al. (2003), if the consumer defection decreases by 5 per cent, then the profits increase by $25-80$ per cent in service industry. A major component of customer retention involves understanding consumer complaint behavior for better designed marketing activities (Henning-Thurau, 2000; Rust et al., 1993; Tax et al., 1998). For instance, Grönroos (2003) identifies customer focus as an essential dimension similar to finance and human resources, implying that a business must listen to and understand their complaining customers in order to maintain a long relationship, which is in turn useful for achieving financial goals.

Consumer complaint behavior has drawn attention in marketing literature (Day\&Landon, 1977; Jacoby\&Jaccard, 1981; Singh, 1988). Previous studies investigated the impact of demographic

\footnotetext{
* This paper was presented at the Annual Paris Business Research Conference, 13-14 August 2015.
} 
characteristics such as age, gender and education (Day\&Landon, 1977; Herrman et al., 1975; Han et al., 1995). Similarly, an alternative variable that may explain and predict consumer preference for one modality over another is the "personality type" (Harrington\&Loffredo, 2009). Consumers in different personality types can choose to exercise different types of complaint behavior with different intentions. Understanding the effects of different consumer personality types on consumer complaint behavior can help marketers to improve consumers' perceptions of service quality further.

The purpose of this paper is, therefore, to explore the potential differences and similarities in attitudes toward complaint behaviors among different personality types. The results will be valuable in assisting marketing managers in understanding the customer complaint behavior with regard to personality types.

The remainder of the paper is organized as follows: a brief presentation of the personality types includes Jung's theory, Myers-Briggs type theory and customer complaint behavior literature review. This is followed by the proposed research hypotheses and the research methodology. The analysis of the collected data and testing of the hypotheses are complemented by a discussion of the main results with regard to the customer complaint literature. The article ends with a revision of the main findings, limitations of this study, and future research directions.

\section{LITERATURE REVIEW}

\subsection{The Myers-Briggs Type Theory}

The concept of personality types was first proposed by the psychiatrist Carl Jung, whose ideas were later improved by Briggs and Myers into a practical self-report instrument called the MyersBriggs Type Indicator (MBTI) (Saggino et al., 2001; Harrington\&Loffredo, 2009). MBTI is one of the most popular psychological instruments to measure an individual's preference (Zardouz, 2011), attitudes and perceptions (Buboltz, 2000). Contemporary business practice still benefits from MBTI with approximately three million individuals filling the questionnaires every year. During the last decade, many human resources departments have continued to utilize MBTI to measure management ability in various contexts (Young\&Walters, 2002) and to enhance selfknowledge, interpersonal understanding and teamwork (Garrety, 2007).

Jung initially identified two major personality orientations: extroversion and introversion along with four fundamental psychological functions: Extroversion (E) - Introversion (I), Sensing (S) - Intuition (N), Thinking (T) - Feeling (F) Judging (J) - Perceiving (P) (McKenna, 2001), suggesting that individuals exhibit one of 16 possible personality types based on 4 dimensions with 2 possible levels in each $(2 \times 2 \times 2 \times 2)$ (Hough, 2005). In Table 2, all the possible personality types are shown.

The first dimension involves the extraversion and introversion levels. Extraversion refers to a person whose mental processes are directed at the outer world of people while introversion refers to an orientation towards the inner world of people. The second dimension involves sensing and intuition. Sensing involves receiving information directly through the five senses while intuition involves discovering possibilities, which might not be immediately obvious from sensory data. The third dimension encompasses thinking and feeling. Thinking involves the logical analysis of information while feeling measures the emotional value that is attached to objects or events. Lastly, the fourth dimension involves judging and perceiving. Judging is concerned with organizing and processing information while perceiving is concerned with directly receiving information without evaluation (Furnham et al., 2003). Table 1 summarizes the focus, preferences and potential strengths and weaknesses of these different levels of personality types (Gardner\&Martinko, 1996). 
Table 1

Summary of Purported Personality Type Preferences and Characteristics

\begin{tabular}{|c|c|c|c|}
\hline Personality Types & Focus and Preferences & Strengths & Weakness \\
\hline $\begin{array}{l}\text { Extroversion } \\
\text { (E) }\end{array}$ & $\begin{array}{l}\text { Energized by outer world; } \\
\text { focus on people and } \\
\text { things; active; breadth } \\
\text { of interest; interactive; } \\
\text { sociable; and outgoing. }\end{array}$ & $\begin{array}{l}\text { Good at social interaction; } \\
\text { enthusiastic and confident; } \\
\text { stimulates communication and } \\
\text { ideas; instigates action; open and } \\
\text { straightforward. }\end{array}$ & $\begin{array}{l}\text { Intellectual superficiality; } \\
\text { intrusive; lack of respect } \\
\text { for others' privacy; easily } \\
\text { distracted by external stimuli. }\end{array}$ \\
\hline $\begin{array}{l}\text { Introversion } \\
\text { (I) }\end{array}$ & $\begin{array}{l}\text { Energized by inner world; } \\
\text { focus on thoughts and } \\
\text { concepts; reflective; depth } \\
\text { of interest; concentration; } \\
\text { inwardly directed. }\end{array}$ & $\begin{array}{l}\text { Good at personal interaction; } \\
\text { stays calm and focused; can } \\
\text { concentrate intensely; develops } \\
\text { ideas; uses discretion in talking. }\end{array}$ & $\begin{array}{l}\text { May lose touch with outer } \\
\text { world; bottles up emotions; } \\
\text { keeps people at a distance; } \\
\text { easily preoccupied; gives } \\
\text { insufficient feedback. }\end{array}$ \\
\hline $\begin{array}{l}\text { Sensing } \\
\text { (S) }\end{array}$ & $\begin{array}{l}\text { Facts; data; details; } \\
\text { concrete; practical; } \\
\text { reality-based; present- } \\
\text { oriented; utility. }\end{array}$ & $\begin{array}{l}\text { Pragmatic; precise; stable; } \\
\text { results-oriented; sensible; } \\
\text { systematic; bases opinions } \\
\text { on observations. }\end{array}$ & $\begin{array}{l}\text { Lacks long-range outlook; } \\
\text { may overlook implications } \\
\text { and meanings; may reject } \\
\text { innovative ideas. }\end{array}$ \\
\hline $\begin{array}{l}\text { Intuition } \\
(\mathrm{N})\end{array}$ & $\begin{array}{l}\text { Meanings; associations; } \\
\text { possibilities; hunches, } \\
\text { speculations; theoretical; } \\
\text { future-oriented; novelty. }\end{array}$ & $\begin{array}{l}\text { Imaginative; conceptualizes } \\
\text { easily; creative; holistic } \\
\text { perspective; intellectually } \\
\text { tenacious; idealistic. }\end{array}$ & $\begin{array}{l}\text { Unrealistic; out-of-touch; } \\
\text { may overlook key variables } \\
\text { or facts; bored by routine; } \\
\text { scattered; overcomplicates. }\end{array}$ \\
\hline $\begin{array}{l}\text { Thinking } \\
\text { (T) }\end{array}$ & $\begin{array}{l}\text { Analysis; objective; logic; } \\
\text { impersonal; critique; } \\
\text { reason; criteria; justice; } \\
\text { systematic inquiry; } \\
\text { principles. }\end{array}$ & $\begin{array}{l}\text { Rational; logical; analytical; } \\
\text { assertive; deliberative; carefully } \\
\text { weighs alternative; firm but fair; } \\
\text { explains thoroughly. }\end{array}$ & $\begin{array}{l}\text { Undervalues or suppresses } \\
\text { own and others' feelings; } \\
\text { overly analytical; cold; } \\
\text { insensitive; critical; } \\
\text { judgmental; overly formal. }\end{array}$ \\
\hline $\begin{array}{l}\text { Feeling } \\
\text { (F) }\end{array}$ & $\begin{array}{l}\text { Sympathy; consideration; } \\
\text { subjective; humane; } \\
\text { personal; trust; harmony; } \\
\text { empathy; appreciates } \\
\text { values; compassion; } \\
\text { altruistic }\end{array}$ & $\begin{array}{l}\text { Persuasive; empathic; warm; } \\
\text { sensitive; demonstrative and } \\
\text { expressive; draws out feelings } \\
\text { of others; loyal; committed to } \\
\text { values. }\end{array}$ & $\begin{array}{l}\text { Overly sensitive; moody; } \\
\text { may give indiscriminately; } \\
\text { can become emotionally } \\
\text { overburdened; unable to give } \\
\text { unpleasant feedback }\end{array}$ \\
\hline $\begin{array}{l}\text { Judging } \\
\text { (J) }\end{array}$ & $\begin{array}{l}\text { Organized; planned; } \\
\text { settled; closure; controls } \\
\text { one's life; sets goals; } \\
\text { structured; routine. }\end{array}$ & $\begin{array}{l}\text { Plans, organizes, and controls } \\
\text { well; persistent; life is } \\
\text { well-structured; decisive; } \\
\text { conscientious; reliable. }\end{array}$ & $\begin{array}{l}\text { Closed-minded; inflexible; } \\
\text { can jump to conclusions too } \\
\text { quickly; intolerant; critical; } \\
\text { judgmental. }\end{array}$ \\
\hline $\begin{array}{l}\text { Perceiving } \\
\text { (P) }\end{array}$ & $\begin{array}{l}\text { Pending; flexible; curious; } \\
\text { spontaneity; tentative; } \\
\text { lets life happen; open to } \\
\text { change; undaunted by } \\
\text { surprise. }\end{array}$ & $\begin{array}{l}\text { Open-minded; adaptable; } \\
\text { spontaneous; understanding; } \\
\text { tolerant; inquisitive; zest for } \\
\text { experience. }\end{array}$ & $\begin{array}{l}\text { Indecisive; procrastinates; } \\
\text { unfocused; disorganized; } \\
\text { impulsive; may collect data } \\
\text { too long before deciding. }\end{array}$ \\
\hline
\end{tabular}

Source: Adapted from Gardner\&Martinko, 1996:47.

Management literature often visits cognitive styles that utilize Jung's theory of psychological types and MBTI as a widely accepted approach to measure personality of managers. Cognitive style is defined as "an individual difference in how people perceive, think, solve problems, learn, motive and relate to each other" (Hough, 2005) and identified in four categories which are sensing-thinking $(S T)$, sensing-feeling $(S F)$, intuition-thinking $(N T)$ and intuition-feeling $(N F)$ (Gallen, 2009). ST individuals are practical, guardian and logical. They show immediate responses and feedback in any situation. $S F$ individuals share feelings and experiences with other people during the process of judging. $N F$ individuals are intuitive and highly idealistic. They focus on 
other people for effective communication. Finally, NT individuals are rational and inventive. They can also be described as being debater and defensive (Gallen, 2009; McPhail, 2002). This paper extends these four cognitive styles with the combination of sixteen MBTIs.

Figure 1

16 personality types of MBTI and the classification of MBTI types

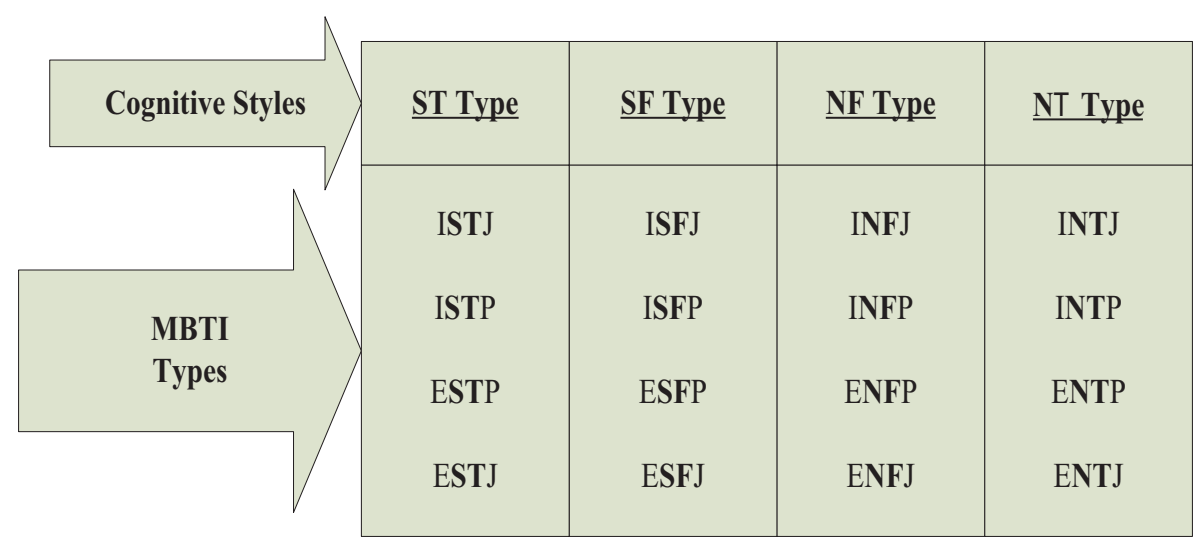

Source: Hough J.R. and Ogilvie D. (2005) “An empirical test of cognitive style and strategic decision outcomes”, Journal of Management Studies, $42(2), 417-448$.

\subsection{Customer Complaint Behavior}

Numerous studies have investigated the possible link between personality types and customer behavior (Davidow\&Dacin, 1997; Bodey\&Grace, 2006). It is found that individual differences in personality influence behavior (Mowen\&Speers, 1999). Similarly, personality types such as extroversion or introversion have been reported to have significant effects on consumer behavior including purchasing, changes in attitude and complaint behavior (Bodey\&Grace, 2006).

Customer complaint behavior is defined by Ngai et al. (2007), as, “... an action taken by an individual which involves communicating something negative regarding a product or service either to the firm manufacturing or marketing that product or service or to some third-party organizational entity". There are many factors influencing customer complaint behavior, such as situational variables, product and personal variables, and the intensity of the consumer's dissatisfaction (Volkov et al., 2002). Customer complaint behavior is reported as a function of dissatisfaction which results from the negative disconfirmation associated with the related purchasing expectations (Heung\&Lam, 2003). Moreover, there is an opportunity for building customer loyalty upon reflecting seriously on customer complaints (Hansen et al., 2010).

There is emerging research adopting a multidimensional perspective to predict and explain consumer complaint behavior. (Kitapci\&Dortyol, 2009; Phau\&Baird, 2008; Liu\&McClure, 2001). For example, Mattila and Wirtz (2004) refer to Day and Landon's (1977) categorization of complaint behaviors with a two-level hierarchical classification (Figure I) where the first level distinguishes between non-behavioral (non-action) and behavioral (take action) actions stemming from dissatisfaction. Some dissatisfied consumers prefer doing nothing as a legitimate response (Phau\&Sari, 2004) while others take some form of action. The second level varies from private action, which includes specific actions such as boycotting a firm's brand and products, negative word-of-mouth communication to friends, relatives and/or other people face-to-face or in social networks, to public action, which includes specific actions such as seeking redress directly, instigating legal actions and taking direct complaint actions to consumer agencies or government.

Whether any dissatisfied customer will take an action or not is the result of a decision-making process. If the individual chooses to take an action due to a bad experience, how the complaint will 
be raised also involves another intrinsic decision-making. It is reported that introvert individuals are more inclined to engage in private complaint actions such as exiting or boycotting the firm brand and negative word-of-mouth. Extroverts, on the other hand, exhibit engagement with public complaint actions such as seeking redress directly and taking direct complaint actions to third party (Davidow\&Dacin 1997). However, personality types and cognitive styles extend to more alternatives than introversion and extroversion, which are yet to be investigated within the domain of complaint behavior research. This paper aims to extend the literature in this particular focus.

Figure 2

Classification of Customer Complaint Behavior

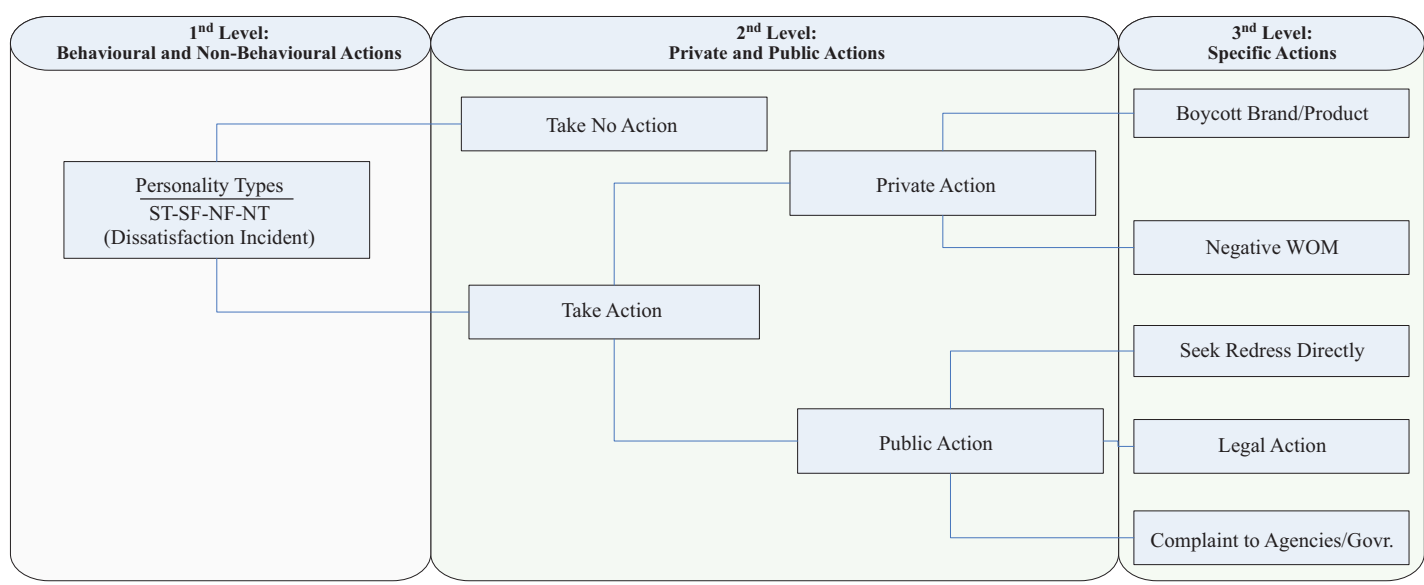

Source: Adapted from Mattila and Wirtz, 2004.

\section{METHODOLOGY}

Individuals with different personality types may choose to exhibit different complaint behaviors upon a dissatisfactory experience. This study aims to understand the differences and similarities in the consumer complaint behaviors of individuals with different personality types and cognitive styles. The scope and the depth of this study is extended to a series of hypothesis.

$\mathrm{H}_{1}$ : There is a significant difference in the complaint behaviors among different personality types (ST, SF, NF, NT) in terms of: (a) public complaints, (b) private complaints and (c) no action.

$\mathrm{H}_{1-\mathrm{a}}$ : There is a significant difference among personality types (ST, SF, NF, NT) in relation to the actions of a public complaint. $\mathrm{H}_{1-\mathrm{b}}$ : There is a significant difference among personality types (ST, SF, NF, NT) in relation to the actions of a private complaint. $\mathrm{H}_{1-\mathrm{c}}$ : There is a significant difference among personality types (ST, SF, NF, NT) in relation to the actions of no action.

The MBTI personality test was applied to managers of a finance company who were then asked to participate in our survey, which consisted of two sections. The first section of the questionnaire includes 9 items on a 5-point Likert scale for data collection, with " 1 " as "strongly disagree" and "5" as "strongly agree" (Likert, 1934), to measure dissatisfied complaint actions at the levels of no action, public and private actions. The second section includes questions regarding the demographic profiles (age, education level, income and gender) of the respondents. A pilot test of the questionnaire was completed in early February 2013 by the participation of four university staff. Pilot test respondents did not report any problems but a few minor wording change suggestions. 
Subsequent to the satisfactory pilot test, a large-scale consumer questionnaire was administered by two graduate students to the managers of a large finance company in Turkey. 121 of the 168 managers were chosen based on the MBTI test results, and 116 of these participated in our questionnaire. Five managers were not included in the analysis because they were unavailable for reasons of annual leave, maternity leave etc., although they were included in the sample. Respondents completed the questionnaire in their mother tongue, Turkish. SPSS 19.0 for Windows was used for data analysis. Descriptive statistics such as means, frequencies, One-Way ANOVA test were calculated. Reliability and internal consistency of statements are measured by Cronbach's Alpha coefficient values.

Table 2

Demographic breakdown of respondents $(n=116)$

\begin{tabular}{c|c|c|c|c|c}
\hline Age & f & \% & Education & f & \% \\
\hline $26-29$ & 17 & 14.6 & High/Commerce School & 11 & 9.5 \\
\hline $30-33$ & 38 & 32.8 & Bachelor's Degree & 77 & 66.3 \\
\hline $34-37$ & 33 & 28.5 & Master's Degree & 25 & 21.6 \\
\hline $38-41$ & 28 & 24.1 & Ph.D. Degree & 3 & 2.6 \\
\hline Total & $\mathbf{1 1 6}$ & $\mathbf{1 0 0 . 0}$ & Total & $\mathbf{1 1 6}$ & $\mathbf{1 0 0 . 0}$ \\
\hline Gender & $\mathbf{f}$ & $\mathbf{\%}$ & & $\mathbf{f}$ & $\mathbf{\%}$ \\
\hline Female & 35 & 30.2 & Lower Income & 15 & 12.9 \\
\hline Male & 81 & $\mathbf{6 9 . 8}$ & Average Income & 76 & 65.5 \\
\hline Total & $\mathbf{1 1 6}$ & $\mathbf{1 0 0 . 0}$ & Higher Income & 25 & 21.6 \\
\hline & & & Total & $\mathbf{1 1 6}$ & $\mathbf{1 0 0 . 0}$ \\
\hline
\end{tabular}

Table 2 summarizes the demographics of the respondents. The sample of respondents contained approximately 70 per cent males and 30 per cent females. 14.6 per cent of the respondents were aged between 26 and 29 years, 32.8 per cent were aged between 30 and 33 years, 28.5 per cent aged between 34 and 37 years, and 24.1 per cent aged between 38 and 41 years. Close to 73 per cent of the respondents were married. 66.3 per cent of the respondents had bachelor's degree while 2.6 per cent of the respondents had Ph.D. degree. In terms of spending power, the majority of the participants subjectively thought that their incomes were average compared to other consumers.

\subsection{Findings}

The Cronbach's Alpha test was applied to assess the internal consistency and reliability of the scales. The Cronbach's Alpha value calculated for all the items was 0.784 .

The Cronbach's Alpha value for four items of public action was 0.87 and for the four items in private action alpha was 0.73 . But for no-action there is no value due to the limited number of items (one item). The mean values, maximum and minimum values, standard deviations, number of items and reliability analysis are summarized in Table 3. Literature reports that 44 per cent of consumers who are dissatisfied with a service make a complaint directly to the business (Bolfing, 1989). Our results indicate that complaining directly to a manager has the highest score, as well.

ANOVA, a hypothesis testing the procedure to evaluate the mean differences between two or more populations, was employed to analyze the data collected from the questionnaire survey. The mean difference is statistically significant in this study at the 1 per cent level when the corresponding significant value is equal to or less than 0.01 . One-way analyses of variance 
(ANOVA) were conducted on the mean scores of all sources and effects of stress across the four groups (sensing-thinking $(S T)$, sensing-feeling $(S F)$, intuition-thinking $(N T)$ and intuition-feeling $(N F))$. Scheffe's test, which has been developed to compare all possible linear combinations between groups, is accepted as the most flexible post hoc type as it can stake out the error when the number of groups is high and as it pays no attention to the assumption that states the number of observations is equal in groups. For the purpose of this article, only significant results $(p<0.01)$ are reported.

Table 3

Descriptive Statistics of Variables

\begin{tabular}{|c|c|c|c|c|c|}
\hline $\begin{array}{l}\text { Variables } \\
(1-5 \text { Scale })\end{array}$ & Mean & Std. Dev. & Min-Max & Cronbach's $\alpha$ & Items \\
\hline PUBLIC ACTION & 3.75 & 0.873 & $2.0-5.0$ & 0.87 & 4 \\
\hline Complain to manager & 4.25 & 0.903 & & & \\
\hline Write a complaint letter & 3.85 & 1.049 & & & \\
\hline Report to legal office & 3.45 & 1.074 & & & \\
\hline Report the problem to consumer agency & 3.44 & 1.074 & & & \\
\hline PRIVATE ACTION & 4.06 & 0.535 & $2.8-5.0$ & 0.73 & 4 \\
\hline $\begin{array}{l}\text { Speak to friends/relatives about bad } \\
\text { experience }\end{array}$ & 4.37 & 0.666 & & & \\
\hline Warn friends/relatives & 4.34 & 0.709 & & & \\
\hline Stop using product (forsaking) & 3.95 & 0.828 & & & \\
\hline Speak to friends/relatives in social network & 3.56 & 0.887 & & & \\
\hline NO ACTION & 1.41 & 0.646 & $1.0-4.0$ & - & 1 \\
\hline
\end{tabular}

Table 4

ANOVA Test for Personality Types As Regards Complaint Behaviors

\begin{tabular}{|c|c|c|c|c|c|c|c|c|c|c|}
\hline $\begin{array}{l}\text { Complaint } \\
\text { Behaviors }\end{array}$ & & $\begin{array}{c}\text { ST } \\
(n=33) \\
\text { Mean }\end{array}$ & $\begin{array}{c}\text { SF } \\
(n=33) \\
\text { Mean }\end{array}$ & $\begin{array}{c}\text { NF } \\
(n=33) \\
\text { Mean }\end{array}$ & $\begin{array}{c}\text { NT } \\
(\mathrm{n}=33) \\
\text { Mean }\end{array}$ & $\begin{array}{l}\text { Sum of } \\
\text { Squares }\end{array}$ & df & $\begin{array}{c}\text { Mean } \\
\text { Square }\end{array}$ & F & Sig. \\
\hline \multirow{3}{*}{$\begin{array}{l}\text { Public } \\
\text { Action }\end{array}$} & Inter-groups & \multirow{3}{*}{4.48} & \multirow{3}{*}{2.55} & \multirow{3}{*}{3.63} & \multirow{3}{*}{4.33} & 67.669 & 3 & 22.556 & 126.996 & 0.000 \\
\hline & Intra-groups & & & & & 19.893 & 112 & 0.178 & & \\
\hline & Total & & & & & 87.562 & 115 & & & \\
\hline \multirow{3}{*}{$\begin{array}{l}\text { Private } \\
\text { Action }\end{array}$} & Inter-groups & \multirow{3}{*}{3.52} & \multirow{3}{*}{4.41} & \multirow{3}{*}{4.22} & \multirow{3}{*}{4.16} & 14.018 & 3 & 4.673 & 27.738 & 0.000 \\
\hline & Intra-groups & & & & & 18.867 & 112 & 0.168 & & \\
\hline & Total & & & & & 32.957 & 115 & & & \\
\hline \multirow{3}{*}{$\begin{array}{c}\text { No } \\
\text { Action }\end{array}$} & Inter-groups & \multirow{3}{*}{1.21} & \multirow{3}{*}{1.17} & \multirow{3}{*}{1.70} & \multirow{3}{*}{1.58} & 6.170 & 3 & 2.057 & 5.513 & 0.001 \\
\hline & Intra-groups & & & & & 41.786 & 112 & 0.373 & & \\
\hline & Total & & & & & 47.957 & 115 & & & \\
\hline
\end{tabular}


We carried out a one-way analysis of variance (ANOVA) to analyze if the mean values of personality types are significantly different in relation to public action, private action and no action (Table V). The results showed that there are significant differences in relation to public action $(\mathrm{F}=126.996 ; \mathrm{p}<0.000)$, private action $(\mathrm{F}=27.738 ; \mathrm{p}<0.000)$ and no action $(\mathrm{F}=5.513$; $\mathrm{p}<0.01)$.

Accordingly, $S T$ individuals choose to complain via private actions less while $S F$ individuals choose to complain via public actions less than the other personality types. Besides, $N F$ individuals are more inclined to choose no action for complaint when compared to $S T$ and $S F$ individuals.

Table 5

Homogenous subsets from Scheffe's test for public, private actions and no action

\begin{tabular}{|c|c|c|c|c|}
\hline \multirow{2}{*}{ Variables } & \multirow{2}{*}{$\mathbf{N}$} & \multicolumn{3}{|c|}{ Subset for $\alpha=0.05$} \\
\hline & & 1 & 2 & 3 \\
\hline \multicolumn{5}{|c|}{ FOR PUBLIC ACTION } \\
\hline SF & 29 & 2.55 & & \\
\hline NF & 30 & & 3.63 & \\
\hline NT & 24 & & & 4.33 \\
\hline ST & 33 & & & 4.48 \\
\hline Significance & & 1.000 & 1.000 & 0.645 \\
\hline \multicolumn{5}{|c|}{ FOR PRIVATE ACTION } \\
\hline ST & 33 & 3,52 & & \\
\hline NT & 24 & & 4.16 & \\
\hline NF & 30 & & 4.22 & \\
\hline SF & 29 & & 4.41 & \\
\hline Significance & & 1.000 & 0.768 & \\
\hline \multicolumn{5}{|c|}{ FOR NO ACTION } \\
\hline SF & 29 & 1.17 & & \\
\hline ST & 33 & 1.21 & & \\
\hline NT & 24 & & 1.58 & \\
\hline NF & 30 & & 1.70 & \\
\hline Significance & & 0.97 & 0.914 & \\
\hline
\end{tabular}

A post hoc analysis (Scheffe's test) shows where the significant intra-group differences occur (Table VI). Accordingly, $N T(\mu=4.33)$ and $S T(\mu=4.48)$ individuals are more likely to engage in public complaint behavior than $S F(\mu=2.55)$ and $N F(\mu=3.63)$ individuals. Moreover, $S F$ $(\mu=4.41), N F(\mu=4.22)$ and $N T(\mu=4.16)$ individuals are more likely to engage in private complaint behavior than $S T(\mu=3.52)$ individuals, respectively. Finally, $N F(\mu=1.70)$ and $N T$ $(\mu=1.58)$ individuals are more likely to choose no action for exhibiting complaint behavior than $S T(\mu=1.21)$ and $S F(\mu=1.17)$ individuals. These findings result in the rejection of the null hypothesis with regard to $\mathrm{H}_{1-\mathrm{a}}, \mathrm{H}_{1-\mathrm{b}}$ and $\mathrm{H}_{1-\mathrm{c}}$. 


\section{DISCUSSION}

Sensing-Feeling and Intuition-Feeling individuals have been described to share feelings and experiences with others via effective communication during the process of judging by the management literature. Our results reveal that Sensing-Feeling $(\mu=4.41)$ and IntuitionFeeling $(\mu=4.22)$ individuals are more willing to engage in private complaining actions such as negotiation, word-of-mouth with friends and family when compared to other personality types. On another note, altruism, concern for the welfare of others (Velazquez et al., 2010) is seen as a characteristic of Feeling (Furnham et al., 2003) individuals, and it is related to negative word-of-mouth (Chelminski\&Coulter, 2011). Thus, Sensing-Feeling and Intuition-Feeling individuals are altruistically motivated to help others. Referring to the other characteristics of Feeling, as being persuasive, demonstrative and expressive, and Intuition, as conceptualizing his/her idea easily, Intuition-Feeling individuals are driven to engage in effective communication.

The results indicate that Sensing-Thinking $(\mu=4.48)$ and Intuition-Thinking $(\mu=4.33)$ individuals are more inclined to engage in public complaint behaviors including complaining directly to the business or using other public complaint instruments. Within the scope of SensingThinking, being logical and showing immediate responses and feedback in any situation can be seen as the reasons to complain directly. Likewise, for Intuition-Thinking individuals, being rational and debater are the motivators that lead them to public actions. Accordingly, with the influences of being results-oriented, as a strength of Sensing, and explaining thoroughly, as a strength of Thinking, Sensing-Thinking individuals seek redress directly. As distinct from Sensing-Thinking people, Intuition-Thinking individuals, who are idealistic, feel themselves taking part in public actions and spending time and making efforts in legal actions.

Finally, the results emphasize that Intuition-Feeling $(\mu=1.70)$ individuals choose to take no actions related with their bad experiences. However, Intuition-Feeling individuals are defined as idealistic; therefore, a complaint action could be expected from these individuals. Yet, the strength of Feeling could result in loyalty, which is coupled with oversensitivity, might prevent these individuals from raising a complaint. In other words, loyalty combined with oversensitivity might lead to no actions of complaint despite the idealistic state.

\subsection{Conclusion}

The purpose of this paper is to explore the potential differences and similarities in attitudes toward complaint behaviors among different personality types. The present study provides invaluable managerial cues for a deeper understanding of the underlying motivations with regard to personality characteristics of both complaining and non-complaining behaviors of customers.

Finally, the results show that Intuition-Thinking and Sensing-Thinking individuals tend to engage in public action, while Sensing-Feeling individuals prefer to take private action, and Intuition-Feeling individuals take no action, which is a different form of complaint behavior.

\subsection{Limitations of the Study and Recommendations for Future Research}

The ability to generalize our research findings is limited by the limited scope of the participants surveyed. As the sample only contains managers, a wider range of consumer population is not represented. Besides, as the possibility that the managers may have the characteristics of their industry was ignored, the generalization of the results to other industries may seem unfounded. Therefore, future research should take this point into account. Moreover, the effects of environmental factors may differ depending on the different demographic characteristics such 
as age, gender, income and/or education. Future research is required to collect data from the various segments of customers with an increased sample size in order to analyze the proposed theory in this paper. Furthermore, the use of a longitudinal approach might provide a better insight into customer complaint behavior for different product categories.

\section{References}

Blodgett J.G., Wakefield K.L. \& Barnes J.H. (1995). The effect of customer service on consumer complaining behavior, Journal of Services Marketing, 9(4), 31-42.

Bodey K. \& Grace D. (2006). Segmenting service "complainers" and "non-complainers" on the basis of consumer characteristics, Journal of Service Marketing, 20(3), 178-187.

Bolfing C.P. (1989). How do customers express dissatisfaction and what can service marketers do about it?, Journal of Service Marketing, 3(3), 5-23.

Buboltz W.C., Johnson P., Nichols C., Miller M.A. \& Thomas A. (2000). MBTI personality types and SII personality style scales, Journal of Career Assessment, 8(2), 131-145.

Chelminski P. \& Coulter R.A. (2011). An examination of consumer advocacy and complaining behavior in the context of service failure, Journal of Service Marketing, 25/5, 361-370.

Davidow M. \& Dacin P.A. (1997). Understanding and influencing consumer complaint behavior: improving organizational complaint management, Advances in Consumer Researcher, (24), 450-456.

Day R.L. (1977). Extending the concept of consumer satisfaction, Advances in Consumer Research, 4(1), 149-154.

Day R.L. \& Landon E.L. (1977). Toward a Theory of Consumer Complaint Behavior: Consumer and Industrial Buying Behavior, North-Holland, New York, NY, 425-437.

Duffy D.L (2003). Commentary: Internal and External Factors Which Affect Customer Loyalty, Journal of Consumer Marketing, 20(5), 480-485.

Furnham A., Moutafi J. \& Crump J. (2003). The relationship between the revised neo-personality inventory and the myers-briggs type indicator, Social Behavior and Personality, 31(6), 577-584.

Gallen T. (2009). Top management team composition and views of viable strategies, Team Performance Management, $15(7 / 8), 326-342$.

Gardner W.L. \& Martinko M.J. (1996). Using the Myers-Briggs Type Indicator to Study Managers: A Literature Review and Research Agenda, Journal of Management, 22(1), 45-83.

Garrety K. (2007). Beyond ISTJ: A discourse-analytic study of the use of the Myers-Briggs Type Indicator as an organizational change device in an Australian industrial firm, Asia Pacific Journal of Human Resources, 45(2), 218-234.

Grönross C. (2003). Taking a customer focus back into the boardroom: can relationship marketing do it?, Marketing Theory, 3(1),171-173.

Han S., Keng K.A. \& Richmond D. (1995). Determinants of consumer complaint behavior: a study of Singapore consumers, Journal of International Consumer Marketing, 8(2), 59-76.

Hansen T., Wilke R. \& Zaichkowsky J. (2010). Managing consumer complaints: Differences and similarities among heterogeneous retailers, International Journal of Retail and Distribution Management, 38 (1), 6-23.

Harrington R. \& Loffredo D.A. (2009). MBTI personality type and other factors that relate to preference for online versus face-to-face instruction, Internet and Higher Education, 13, 89-95.

Hennig-Thurau T. \& Hansen U. (2000). Relationship Marketing, Springer: Berlin.

Herrman R.O., Warland R.H. \& Willits J. (1975). Dissatisfied consumer: who gets upset and who takes actions, Journal of Consumer Affair, (6), 148-68.

Heung V. \& Lam T. (2003). Customer complaint behavior towards hotel restaurant services, International Journal of Contemporary Hospitality Management, 15(5), 283-289.

Hough J.R. \& Ogilvie D.(2005). An empirical test of cognitive style and strategic decision outcomes, Journal of Management Studies, 42(2), 417-448.

Jacoby J. \& Jaccard J.J. (1981). The sources, meaning, and validity of consumer complaint behavior: a psychological analysis, Journal of Retailing, 57(3), 4-23.

Kitapci O. \& Dortyol I.T. (2009). The differences in customer complaint behavior between loyal customers and first comers in the retail banking industry: The case of Turkish customers, Management Research News, 32(10), 932-941.

Lee S.C., Barker S. \& Kandampully J. (2003). Technology, Service Quality and Customer Loyalty in Hotels: Australian Managerial Perspectives, Managing Service Quality, 13(5), 423-432.

Likert R. (1934). A simple and reliable method of scoring the turnstone attitude scales, Journal of Social Psychology, (5), 228. 
Liu R. \& McClure P. (2001). Recognizing cross-cultural differences in consumer complaint behavior and intentions: an empirical examination, Journal of Consumer Marketing, 18(1), 54-74.

Mattila A.S. \& Wirtz J. (2004). Customer complaining to firms: The determinants of channel choice, Journal of Service Marketing, 18(2), 147-155.

McKenna M.K., Shelton C.D. \& Darling J.R. (2001). The impact of behavioral style assessment on organizational effectiveness: A call for action, Leadership Organization Development Journal, 23(6), 314-322.

McPhail K.J.A. (2002). The nursing profession, personality types and leadership, Leadership in Health Service, $15(1)$, vii-x.

Mowen J.C. \& Spears N. (1999). Understanding compulsive buying among college students: A hierarchical approach, Journal of Consumer Psychology, 8(4), 407-430.

Ngai E.W.T., Heung V.C.S., Wong Y.H. \& Chan F.K.Y. (2007). Consumer complaint behaviour of Asians and nonAsians about hotel services: an empirical analysis, European Journal of Marketing, 41(11/12), 1375-1391.

Phau I. \& Baird M. (2008). Complainers versus non-complainers retaliatory responses towards service dissatisfactions, Marketing Intelligence and Planning, 26(6), 587-604.

Phau I. \& Sari R. (2004). Engaging in complaint behavior: an Indonesian perspective, Marketing Intelligence and Planning, 22(4), 407-26.

Rust, R.T. \& Zahorik, A.J. (1993). Customer satisfaction, customer retention, and market share, Journal of Retailing, 69(2), 193-215.

Saggino A., Cooper C. \& Kline P. (2001). A confirmatory factor analysis of Mayers-Briggs Type Indicator, Personality and Individual Differences, 30, 3-9.

Singh, J. (1988). Consumer complaint intentions and behavior: definitional and taxonomical issues, Journal of Marketing, 52(January), 93-107.

Tax S.S., Brown S.W. \& Chandrashekaran M. (1998). Customer Evaluations of Service Complaint Experiences: Implications for Relationship Marketing, Journal of Marketing, 62(2), 60-76.

Velazquez B.M., Blasco M.F., Saura I.G. \& Contri G.B. (2010). Causes for complaining behavior intentions: the moderator effect of previous customer experience of the restaurant, Journal of Service Marketing, 24(7), 532-545.

Volkov M., Harker D. \& Harker M. (2002). Complaint behavior: a study of the differences between complainants about advertising in Australia and population at large, Journal of Consumer Marketing, 19(4), 319-332.

Young A.J. \& Walters J.L. (2002). Relationship between DHI production value and Myers-Briggs type indicator as a measure of management ability, Journal of Dairy Science, 85(8), 2046-2052.

Zardouz S., German M.A., Wu E.C. \& Djalilian H.R. (2011). Personality types of otolaryngology resident applicants as described by the Myers-Briggs type indicator, Otolaryngology, 144(5), 714-718. 